Article

\title{
Rituals, Spacetime and Family in a "Native" Community of North Shanghai
}

\author{
Jiaren Chen * and Benoît Vermander* \\ Department of Religious Studies, School of Philosophy, Fudan University, 220 Handan Road, \\ Shanghai 200433, China \\ * Correspondence: jiarenchen@fudan.edu.cn (J.C.); mdwei@fudan.edu.cn (B.V.)
}

Received: 17 September 2019; Accepted: 14 October 2019; Published: 17 October 2019 updates

\begin{abstract}
China's dramatic process of urbanization has profound influence on the country's religious communities, practices and psyche. This article focuses on a village of North Shanghai that has been integrated into urban life through demolition and relocation at the turn of the century. It follows the evolution of the ritual practices of its former inhabitants until present day. It underlines the fracture that has occurred in the way jia (home/family) was recognized and lived as a focus of ritual activities, and it documents the subsequent enlargement of the ritual sphere that is taking place. The choice of specific temples as privileged places of pilgrimage and ancestral worship is shown to be the result of a combination of factors, relational, geographical, and financial. The study also highlights the fact that the plasticity and inventiveness of the practices observed still testify to the resilience of the "home" concept, whatever the transformation it undergoes, and it links such resilience to the agency of women. By closely following the dynamic of ritual activities in the everyday life of the community under study, the article aims at providing a pragmatic and evolving approach to what "Chinese religion" is becoming in an urban context.
\end{abstract}

Keywords: Chinese religion; urban religiosities; social space; family; lineages; rituals

\section{Introduction}

From less than 20 percent of the nation's total in 1978 (12 percent in 1950), China's urban population had risen to 52 per cent in 2012, and accounted for more than 60 percent in 2019 (United Nations 2014; Worldometers 2019). This corresponds to "the most dramatic urban transformation the world has seen." (Farrell and Westlund 2018, p. 86) The urban population percentage is expected to reach about 70 percent by 2030 (World Bank and Development Research Center of the State Council, the People's Republic of China 2014, p. 3). The impact of such metamorphosis on the religious ecology of the country is necessarily deep and far-reaching. Though the magnitude of the shift has drawn the attention of scholars in Chinese religion (Yao 2007; Goossaert and Palmer 2011, pp. 286-306; van der Veer 2015), detailed accounts of religiosities and spiritual communities in this new urban context have been less numerous and often less thorough than would have been expected. This may be due to the fact that the study of Chinese religion has long been embedded in the solidarities and worldview typical of a peasant society, which created a gap between the tools and concepts originating from Chinese studies and the ones devised by urban sociology. ${ }^{1}$ When China's urban religiosity is being researched, the focus is largely on the growth of Christianity (Yang 2005; Cao 2010; Huang 2014; Kang

1 This statement is to be somehow qualified: Some early works deal with Chinese religion in urban setting-see notably Shryock (1931); Skinner (1977); DeGlopper (1995). However, these works have little relation, if any, with the Chinese city as reshaped by the "Reform and Opening" era. 
2016), a trend reinforced by the fact that recent Christian expansion in China is often explained as being the result of the demise of the religious ecology caused by Maoism (Duan 2011). Still, urban Buddhism has also received its share of attention, including in the context of Shanghai, a city that will be at the center of this article (Huang 2012; Ge 2013; Tarocco 2015).

In the course of the last forty years or so, China has been urbanized through two different phenomena; one is the large-scale migration from the countryside to the city. ${ }^{2}$ The second phenomenon consists in urban extension through rural land requisition and conversion, which made cities absorb the rural population living in their former limits or living at their outskirts. ${ }^{3}$ Such absorption was accompanied by a change in the residency status of the "new" urbanites ${ }^{4}$, but also, and even more importantly, in their housing and occupations.

This article focuses on this second mode of urbanization. It takes as a case-study, two gated communities (xiaoqu 小区 $)^{5}$ of North Shanghai, and it follows the people living there from the turn of the century till the present. ${ }^{6}$ Originally, this twin community was composed exclusively by the inhabitants of a village destroyed when making space for the compound and its surroundings. We investigate the extent to which the inhabitants' ritual practices and the spacetime mark these practices set in order have been remodeled by the successive changes that have occurred. Framing our inquiry along this line, we rely on a few insights progressively gathered by "ritual studies". First, rituals do at least as much as they express (Tambiah 1979). Specifically, they are educators of consciences and practices, and they contribute to transmit and sometimes adapt a set of values. Second, they anchor and "embody" a corpus of local knowledge that defines spatial and temporal settings (Geertz 1973). Third, sometimes unbeknownst to the actors themselves, they undergo a constant process of transformation, as participants need to make sense of the changes affecting their environment-and rituals transformations may prove to go even deeper when the ceremonies performed are said to be "purely" traditional.

Although we focus here upon one single type of community and urban religiosity, our research may shed some light on "Chinese religion", as experienced and practiced today. Rather than offering a formatted definition of what "Chinese religion" is meant to be, this article chooses to approach it through the study of the transformations of the ritual practices of the community discussed below. Marcel Granet may have been the first to approach Chinese religious practices as both a specific religious form and an integrated whole (Granet 1977). Among contemporary scholars; John Lagerwey

2 This phenomenon has been abundantly documented, while statistics present difficulties of interpretation, which accounts for diverging evaluations of its scale and exact significance. Though the general trend is clear, adaptive tactics devised by the migrant populations explain for rapid evolutions in numbers and trends. By 2010, there were 253 million rural residents who had left the agricultural sector (people defined as nongmingong 农民工), representing about 20 percent of the country's total population. Among them, 159 million had migrated outside their place of household registration, the remaining 94 million having transferred from the agricultural to the non-agricultural sector without leaving their district, and over 100 million migrant workers were living in a city for at least six months in a year (Vermander 2014, pp. 153-56). In the last decade, more migrants have been finding work nearby their place of residency. Besides, in the last three years or so, Shanghai and Beijing have proceeded with the expulsion of a large number of migrants. At the same time, plans are underway for expanding residency permits to migrant workers and widening access to housing subsidies and other benefits, but priorities and strategies widely vary from one city to another.

3 From the beginning of the Reform and Opening policy until around 2013, approximately 88 million of peasants have been expropriated from their land and integrated into the urban fabric (Sargeson 2013). It has been noted that "rural land requisition and conversion for industrial use has been particularly inefficient because it has been largely driven by administrative decisions rather than market demand." (World Bank and Development Research Center of the State Council, the People's Republic of China 2014, p. 10)

4 This change has been progressive and convoluted: throughout the 1980s and 1990s, a series of reforms affecting the household registration system relaxed (but certainly did not abolish) restrictions as to the movement of people and rules concerning their place of residency.

5 A term also translated by some scholars as "sealed residential quarter".

6 Jiaren Chen has conducted observation and interviews on the site from 2015 to 2019 continuously. Benoît Vermander has accompanied this research during the same period while conducting fieldwork in adjacent parts of Shanghai and developing questions and tools that led to the publication of (Hingley et al. 2016 and Vermander et al. 2018) prior to the present article.

7 Rudolph (2008) offers an excellent study on the way so-called "retraditionalizing" rituals can be read as an adaptative strategy devised by members of groups subject to rapid and challenging transformations. In the context of Southeastern China see (Chan 1998), which also offers interesting perspectives on the way community rituals work as reservoirs of local knowledge. 
speaks of Chinese (popular) religion as a system of symbolic behaviors that aim to "locate, capture, rejuvenate and cultivate the vital energies circulating" in a given territory (Lagerwey 2010, p. 170). ${ }^{8}$ We are conscious of the dangers inherent to the term "Chinese religion" if understood as an "essence" that would perdure throughout changing times and environments. We chose here to designate by this term a system of transformations. The study of the ritual practices that determine spatial and temporal settings gives privileged access to such system. Seen in this light, our case-study belongs to the corpus of works investigating the transformations having continuously affected the Chinese religious system. At the same time, it specifically deals with the radicalness of the changes that have occurred in the very recent past.

\section{A Community in North Shanghai}

\subsection{North Shanghai: The Setting}

In October 2015, an administrative merger between Jing'an (静安) and Zhabei (闸北) Districts created a "new" Jing' an District, its population over the one million mark and its area accounting for 37 square kilometers. The district has jurisdiction over 13 sub-districts, one town and 276 neighborhood communities. The original Zhabei District is commonly seen as being part of North Shanghai, together with parts of Baoshan (宝山) and Yangpu (杨浦) districts. The dialect that was (and, to a lesser degree, remains ${ }^{9}$ ) spoken in this area is close to that of the Jiading (嘉定) District (originally, a separate city ${ }^{10}$ ) and Taicang (太昌) District (the latter located in Jiangsu Province). As is the case for all variants of the Shanghai dialect, the one spoken on the north of the metropolis is part of the Su-Hu-Jia (苏沪嘉) dialect subgroup of $\mathrm{Wu}$ (吴) Chinese. North Shanghai was for a long time under the jurisdiction of Kunshan (昆山) County in Jiangsu Province, though part of it was attached to Baoshan County.

North Shanghai was also defined by its position within the waterways system of Greater Shanghai and of the Jiangnan (江南) region in general. In Jiangnan, the dense system of channels and rivers were interconnecting local communities into close networks of commerce and worship. Religious devotions were largely conditioned by the way trade on the waterways and sometimes on the sea was conducted: ensuring smooth commercial operations required asking gods and spirits for spiritual protection (be it against the state's operatives, pirates or natural disasters), and such protection was sought after in a network of temples scattered around an area cemented by alliance and commerce (Hamashima 2011; Li 2017).

Within Zhabei, Miaotou (庙头) area was, as indicated by its name, centered around a temple (Miaotou can be roughly translated as "In front of the temple"). The name of the latter, Pengwang Temple (彭王庙), referred to Pengyue, King of Liang (梁王彭越, reigned 203 BC-196 BC), whose spirit was invoked for protecting the villagers against the tide of the Wusong River (吴淞江一also called Suzhou Creek): the tide was affecting the course of the stream crossing the Miaotou area, named Pengyue River (彭越浦), in accordance with the name of its protecting deity. Pengwang Temple was

8 The same author insists on the duality between the "spirituality of the centered self" characteristic of the Chinese (male) literati and territory-based "sacrificial circles" that somehow were and are preserving the agency of women. (Lagerwey 2019, especially pp. 258-73). Among contributions offered by other scholars, Adam Yuet Chau insists on "relationality" as a defining category, Chinese people "doing religion" by establishing and maintaining relationships "between different categories of people; between people and all kinds of supernatural entities, be they deities, ancestors or ghosts; as well as between people, things, and spaces." (Chau 2019, p. 192) Taking Chinese religion at its Late Qing stage, Vincent Goossaert and David Palmer perceive in it a system integrating traditions of individual salvation, moral living, spirit-possession techniques, kinship-based rites, and local cults (Goossaert and Palmer 2011, pp. 20-27). Note also that, in a book that came out at the time this article was being finalized, Jordan Paper makes "familism" the core of Chinese religion. He considers xiao 孝 ("filial piety", or "family reverence" as he prefers to translate) the concept central to the understanding of "familism" (Paper 2019). This attempt, overtly general and ambitious, is less relevant to the present contribution than could been expected.

9 Note that within the compounds that constitute our case-study (see below), the use of this dialect remains predominant.

10 Though it constitutes the north-western corner of the Shanghai municipality, Jiading is considered as being distinct from North Shanghai. 
partly demolished during the Cultural Revolution. What remained of it, located near a well, was fully destroyed in 1997-1998 during the demolition and reconstruction process documented later in this article.

A section of Miaotou was officially renamed Pengpu Town in 1833. At that time, the "town" was only a small plot of land centered around the busy market street that bordered the Pengyue River, Miaotou Street. ${ }^{11}$ The part of Miaotou not included in the new town, close to Pengwang Temple, was simply called Miaotou Village (庙头村). People of Miatou Village were living in traditional extended “residences," (zhai 宅). ${ }^{12}$ On the west of the river, these were the Gu (顾), Xia (夏), “Old Xu” (老徐), "Zhang of the East" (张东), "Zhang of the South" (张南), "Zhang of the Middle" (张中) and "Small Zhang" (小张) residences, while the ones of the "Chen of the Wooden Bridge" (陈家木桥) $)^{13}$ and of the "Zhuang of Luhua" (芦花庄) were located on the opposite riverbank. Until the demolition that occurred at the turn of the present century, these villagers were well-to-do peasants, whose economic condition was considered to be among the best in the district.

Towards the end of the Qing dynasty, the territory of Pengpu Town was substantially enlarged; from that time onwards, it included Miaotou Village and adjacent areas. Another administrative change occurred in 1928 when the inhabitants of the original Miaotou Street received the status of urbanites as the street became part of the Shanghai municipality, which differentiated them further from the Miaotou villagers. Pengpu Town, the locale of the community that we will soon follow, was for a long time predominantly rural. Later on, its workforce began to rely on both farming (peasants were supplying vegetables and pork to the growing number of residents of central Shanghai) and industry (an industrial zone was created during the 1960s). Today, Pengpu Town counts slightly over 150,000 inhabitants. ${ }^{14}$

\subsection{Miaotou Village}

The people of Miaotou Village now live in two gated communities named Guanzhong Court (Guangzhong yuan 广中苑) and Guangsheng Court (Guangsheng yuan 广盛苑). ${ }^{15}$ Before the move took place, each "residence" (zhai) was a plot of land that had been first populated by one or two families ${ }^{16}$ and on which, gradually, other families had also built houses. ${ }^{17}$ For instance, the "Xia Residence" was

11 Miaotou Street was around $200 \mathrm{~m}$ long, one shop succeeding another. According to the recollections of our older interviewees, this was the street where, from 1949 till 1956, inhabitants of the village had to go in order to exchange their food stamps for actual goods.

12 The zhai system would warrant a more extended discussion, which we could not conduct to its term, though the developments that follow will bring some light unto the lived experience it referred to. Most of our information was provided to us by elderly women, who proved to be very familiar with some aspects of village life and structure, and yet extremely unclear about other aspects. One of the reasons is that, for a very long time now, interactions within the production brigade substituted for those among lineages. Besides, land ownership was a topic that, after production brigades were put into place, used not to be discussed, which negatively impacts the amount and accuracy of information now available as to the way residences, in Miaotou, were functioning as a system of corporate holdings.

13 The "Chen of the Wooden Bridge" were actually divided between the western and eastern riverbanks. In the representations of the villagers of Miaotou, people located on the West bank were "natives", while residents of the East bank were migrants from Northern Jiangsu - and yet these "migrants" were settled in Miaotou for at least four generations.

14 Pengpu Town is not to be confused with Pengpu New Village (彭浦新村), which, though located not far away from the former, would warrant a different discussion.

15 Defined as residential areas surrounded by walls, fences, or green hedges (though they do not always impose strict access control-see Yip 2012), gated communities account for more than $80 \%$ of residential communities in Shanghai. See also (Qian 2014), which offers a sociological analysis of neighborhood enclosures as providing, among other features, "the instatement of moral standards and norms" (Qian 2014, p. 14. Our analysis will suggest that these standards are not merely those propounded by the state.) Note that in 2016, the State Council of the PRC issued a directive calling for an end to gated communities. The new policy met with much resistance. In Shanghai, the plan is to slowly 'ungate" compounds through the design of more elastic and permeable boundaries (Wang and Pojani 2019).

16 Later in this article we will be discussed the term "family" and its adequation to the original Chinese (jia 家). In the context of this sentence, we could write "family clan," or "lineage" (jiazu 家族). However, it should be noted that, whatever the dimension of the family unit considered, the people we have been conversing with speak of jia, or, sometimes of jiamen (家门), which (in the local context at least) is not much different, though jiamen resonates more clearly with the term "lineage".

17 The term zhai-which is the one invariably used by the former residents-has also originally the meaning of "settlement" and, sometimes, of burial site, which testifies to the proximity of the concept with the ones of land, family and ancestors. 
first occupied by the Xia family, soon followed by the Chen family. These two clans were considered to be the dominant families of the residence, though other families also settled on this plot later on. Still, the testimonies we collected speak of the atmosphere in the same zhai as similar to the one within a single extended family. Today, elderly people living in the compound remember precisely who was living in which zhai, and these relationships, as we will see, still cement ritual networks.

The zhai system was both maintained and transformed by the new regime: from 1958 onwards, a zhai became the practical equivalent of a production team (shengchan dui 生产队), with the difference that newcomers were arbitrarily sent to one team or another. From maybe twenty or thirty family units at the beginning of the new regime, the Xia Residence had grown to over 60 at the time the demolition occurred. Integrating newcomers was not a new experience for the village: in 1937, the area had been hit hard by the Sino-Japanese war, and a large number of refugees had flooded the area. The destruction that occurred, along with the influx of the migrant population, led many residents to build houses-old-style bungalows - that provided them with housing rents, an important source of income. The double status of house-owner and peasant thus became the distinctive mark of the "locals" (bendiren 本地人) in contrast to the newcomers.

In the collective memory of this local community, agency was a quality bestowed to the family (jia) rather than to the individual. In addition, family identity was doubled and reinforced by the fact of being inserted into a geo-community defined by the position of each zhai within the village as a whole.

Progressive changes in the residency status happened during the 1990s, with most inhabitants of Miaotou village eventually having their registration changed to "city residents". Concurrently, some of them converted into shop-owners. A good number had already been employed as factory workers, sometimes alternating between rural and industrial-based livelihood, ${ }^{18}$ and thus the frontier between rural and urban lifestyles was fluid. However, the demolition of the village, which occurred between 1997 and 2000, was a sudden and radical turning point, though demolition and reconstruction work had already happened in other parts of Pengpu Town. All the families of Miaotou had to eventually move to the new compounds, Guangzhong Court, located on Guangzhong West Road (this first compound will constitute the main locus of our fieldwork) and Guangsheng Court, located on Lingshi Road (see Figure 1).

People had been living in the village's "residences" as extended families for at least three generations. Dispossessed of their land and housing, they were offered in exchange a number of apartments that was dependent on the number of nuclear families comprising the larger family unit. The original territory of the village was of around $1000 \mathrm{mu}$ (most of it used for agricultural purposes). The new park that was built on part of it covers $750 \mathrm{mu}$ and $150 \mathrm{mu}$ were given to a new multimedia center (Shanghai Multimedia Valley, owned by TusPark ${ }^{19}$ ), which left only $100 m u$ for the two residential complexes in which villagers were transferred (2007, and informants). The whole process was surrounded by a certain opacity, and, till now, the former villagers feel that they have not received fair compensation. After relocation they tried various times to appeal, but all their attempts were rejected.

18 The stories collected include the one of the Headmaster of a primary school deciding at some point to revert to farming.

19 In a flourish typical of the rhetoric surrounding the urbanization process the multimedia center was celebrated as "the dream achievement of the Miaotou villagers in the process of urbanization." (2007). 


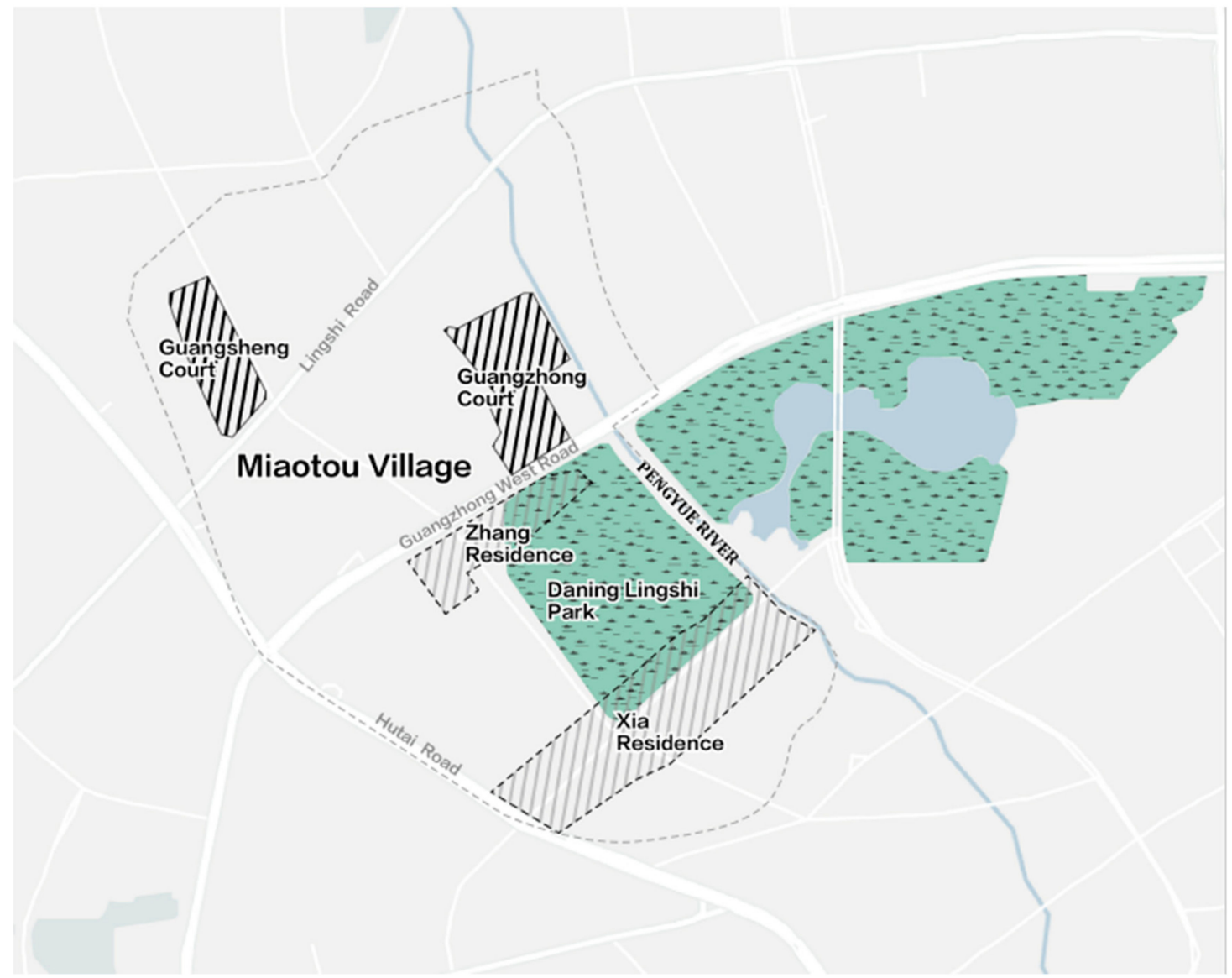

Figure 1. Miaotou Village, Past and Present. Note: Our map includes the outline of the two major residences (zhai) only-the ones of the Xia and the Zhang families.

\section{Entering a New Space}

\subsection{A Shift in Living Patterns}

Around twenty years after the relocation, though postal and administrative indications still make mention of Pengpu Town, it does not correspond to any tangible reality for the average person who walks throughout the roads and streets of Jing'an District. As to Miaotou Village, no one can distinguish the places inhabited by the Gu or the Zhang Family anymore, as one finds only numerals on the buildings of a new community. Where the Xia Residence used to be, now stands a bank building and a portion of the park.

Shifting from one type of housing and community to another meant that living patterns needed to be reinvented. The original site of Miaotou was mainly used by the government for establishing the Daning lingshi (大宁灵石) Park $^{20}$, divided into two sections by the Pengyue River. Under the park runs a tunnel that is meant to alleviate the traffic pressure on the North-South highway. Due to the construction of the park, the inhabitants of the Xia and Zhang residences had to be relocated to the north of their previous location, at Guangzhong Court. ${ }^{21}$ However, the fact that the Pengyue River runs along the east of the new compound made the change more acceptable to them. As Guangzhong Court is located on the original site of the Old Xu Residence, its former inhabitants also joined the new compound. The section of the Chen of the Wooden Bridge located on the West Bank of Pengyue

20 Recently renamed “Daning Tulips Park" (Daning yujinxiang gongyuan 大宁郁金香公园).

21 Moving north is inauspicious, as the city center is on the south. Even in the compound, people are reluctant to move from one apartment to another if the latter is located northwards of the former one. 
was similarly integrated in Guangzhong Court. Guangsheng Court was built on the site of the former Small Zhang residence, whose inhabitants integrated the complex together with the Zhuang of Luhua and the Chen of the East Bank, while families from the other residences were scattered among the two compounds.

Guangzhong Court totals sixty buildings, each of which is six stories ${ }^{22}$ and is comprised of twelve apartments (of two or three rooms alternatively). This makes for a total of 720 apartments. ${ }^{23}$ Guangsheng Court amounts to 43 buildings, divided into 17 buildings of 11 stories (each comprising 22 apartments) and 26 buildings of six stories, which makes for a total of 686 apartments. No apartment could be bought or sold legally within the first ten years after relocation. This contributed much to the fact that, for the first decade, the compounds' population remained largely identical to that of the former residences. ${ }^{24}$ At the same time, the rule was that the apartments' numbers would be drawn in a lottery. Consequently, previous neighborhood relationships disintegrated, and new ones had to be developed. Nonetheless, among extended families, one can still observe today the constant comings and goings from the apartment of one nuclear family to that of its relatives.

\subsection{Moving in}

In China, moving from one location to another was an event of particular importance. It meant that one would have to redefine one's place in a complex network of relationships, with consequences for all parties involved. First, a propitious day had (and often still is) to be determined through the reading of the traditional calendar. And there was a procedure, an etiquette to follow in order to obtain approval from the ancestors to leave one's place and enter another one safely and in peace. So, the day for initiating the demolition process had been carefully determined on the approval of the "residence". 25

In contrast, the day to move to the new location was determined by each nuclear family. ${ }^{26}$ Two days before moving, before the furniture could enter the new house, a representative of the family had to stand in an open space in front of the apartment building so as to report to the local god of the soil (tudishen 土地神) and to the door gods, saying words such as "Grandfather of the soil, Grandmother of the soil, and you Ancestors! We arrive in order to move into this new house [and at this point, say our informants, the address had to be indicated precisely], please give us your blessing!" This was to be followed by the burning of some tin-leaf ingots ${ }^{27}$ and of three incense sticks. After this, the family representative had to go to the upstairs of the apartment, and carefully report to the goddess of the soil. Holding a basin in which papers were burning, she had to ask for blessings first in the living room and then in the bedrooms and the kitchen. One could also have gotten a bell from a temple and struck it throughout the apartment. Additionally, one was to bow and offer some fruits and incense sticks in each room. On the actual move-in day, firecrackers were ignited to report again to the soil and the door gods: "We have arrived!" Bamboo and steamed bread were brought along for these spirits, so as

22 At the time of the construction of the compound, six-story buildings were common in Shanghai, as the rules stipulated that elevators were a requisite only for buildings of seven stories or more.

23 We have already noted the opacity surrounding the allocation process. Official records indicate that the number of nuclear families entering the two compounds was more or less equal to the 1406 apartments that they comprise in total ( 2007) but doubts remain as to the time they were compiled as well as to their accuracy.

24 Notwithstanding the rules, it seems that some trading occurred after the first five years, but the scale of it remained modest.

25 We collected an account of the ceremony for the Xia residence. It took place in the auditorium of the production team. Ancestors were told about the demolition process. The ceremony lasted for around three hours, with eighteen Buddhist monks invited to chant the sutras. Relatives living in other residences were welcome to attend. Note that the inhabitants of the Old Xu and Small Zhang residences did not hold ceremonies, as the new compounds were located on the sites of their respective residences.

26 The fact that the nuclear family only decided on the day of moving into its allocated apartment is of course significant. However, the importance of the observation should be qualified: At that time, the inhabitants were speaking of moving to such or such apartment ("number ten", "number twelve"): The lineage was going to occupy a number of apartments, but it was still as an (undivided) lineage that it was undertaking the operation.

27 Tin leaf ingots (xibo锡箔): spirit paper money used as funeral offerings and burned during the ceremony. 
to ensure good fortune. Later on, at each winter solstice, paper would be burned in honor of the same spirits but also, and most importantly, for appeasing the "neighbors from downstairs" (lou xia de linju 楼下的邻居)—in other words, the ghosts, presumed to be the spirits of the people having lived at this location in the past. $^{28}$

Observing such etiquette was a way to assert one's identity as "locals". Such rituals also created a multi-level sacred space, fulfilling the basic function of separating the "internal" from the "external" while operating within an ascertained system of relationships: the respect paid to, respectively, the god of the soil and his wife was mimicking the division of work between the man of the household, in charge of external affairs, and the woman, in charge of the house proper. Through these rituals, the new apartment was becoming "home", with the spirits of the place invited to enter into a relationship similar to the one that the family nurtures with its ancestors. (The latter are often named after the local word applied to the family altar-jiatang 家堂). Thus, the nuclear family moving in the new apartment was entering at the same time a larger space, the one of a sacred space shared by a larger community ${ }^{29}$, a space in which one has to introduce oneself so that blessings from above may be bestowed upon you. In order to peacefully dwell in the specific portion of a larger sacred space, it was also necessary to implicitly proceed to the expulsion of the putative former inhabitants of the same place, this by relegating them to the status of ghosts-"neighbors from downstairs".

\section{The Ritual Crafting of a Community}

\subsection{Bounding}

Once the people from Miaotou had moved into the new community, they soon realized the extent to which their original life style would be subverted. As there was no arable land, disputes were for some time about the fact that, for many inhabitants, green space was still space available for planting vegetables-which was of course forbidden, green space being "common space", to the great disappointment of these former farmers. Such small-scale cultural clashes frequently happened in many compounds populated by "local" families (including in the New Pudong Area, where many Shanghainese from the downtown area had been relocated) and reverberated throughout the Shanghai local media around the year 2000 and shortly after. As could be expected, the elderly found it most difficult to adapt to life in the compound. At the same time, they were the ones who started to craft a distinct community style: most of their activities took place within the compound; they were taking out the chairs of the apartment so as to sit in the corridor or on the street, before realizing that the garden of the community was a more suitable space. Chairs and sofas were thus arranged at the geographical center of the compound, which somehow became its public area.

After moving into the community, there was no farm work to occupy the time of the elderly, while some middle-aged people could not find a suitable job and used their leisure time in various ways. The newly crafted "agora" of chairs and sofas was-and remains-the space where items of news could be passed along. In the evening, older people return to the apartment-be it the one they live in with their children or the one they occupy by themselves. Local news is communicated from the older generation to the younger one. Middle-aged people get information and shape their opinion on local events not only through their parents but also by attending the informal gatherings in the community "chess rooms," one-story buildings where mah-jong and other games can be played. ${ }^{30} \mathrm{As}$

28 Information used in this paragraph can also be found in (Vermander et al. 2018, p. 115), with slight variations. The main difference between this previous version and the present one is that we are now able to ascertain that the information given to us at that time was directly linked to the experience of moving home underwent by the Miaotou villagers, an experience that has somehow (re)asserted a ritual standard.

29 By "larger community" we understand that of the villagers as structured by the zhai system. It would be wrong to contrast the two: the village presupposes the residence, and the residence the village.

30 The community building where these "chess rooms" are located has been recently renamed "Old People's Home" (laoren zhi jia 老人之家), a testimony to the evolving demographics of the compounds. 
for young people, they would get the latest news during dinner time, and there was no community matter, however small, that they would not hear about.

\subsection{Cleansing}

In 2004, due to the constant flux of insiders' information, the residents of Guangzhong Court were all alerted to the fact that, during the preceding two years, several elderly people in the community had died in succession. They attributed the phenomenon to the place's fengshui. Thus emerged the idea of organizing rituals praying for and asking protection from the ancestors. A certain Grandma Jin (金阿婆) became the natural leader of an organizing group, and along with people originating from the former Xia Residence (in which Grandma Jin used to live) they took it upon themselves to organize the ritual.

Grandma Jin requested and obtained a budget of 10,000 RMB from the brigade chief ${ }^{31}$, and the informal preparatory committee went to each family to ask for additional money, bought the supplies, and prepared red envelopes to be given to the monks. In 2004 and 2005, on the invitation of Grandma Jin, around twenty monks from Haining Temple (海宁禅寺) on Mount Huaguo (花果山) in Jiangsu Province ${ }^{32}$ performed a Buddhist ritual within the compound. The second year, some people suggested that a Daois ceremony should be held as well. Therefore, a Daoist ritual took place before the Buddhist one. A majority of the people were tolerant of the arrangement, observing that the "money and energy were all provided by the community." However, some people refused to contribute money, and told the police that "superstitious activities" were taking place. As the policemen in service were natives from Pengpu Town, they did not think that this was a big deal; they had a look at the event, and went away. However, in 2006, the newly appointed brigade chief resolutely opposed the holding of a ritual within the community's premises. Thus, a Buddhist ritual for the deliverance of the souls (chaodu fahui超度法会) was carried out at the nearby Baohua Temple (宝华寺) ${ }^{33}$. For the last session of this ritual, representatives of practically all families of the community went to the temple, cooking meals there and attending the ceremony. Still, the experience was not repeated. From now on, as we will see below, community worship would take place not only outside the community but also away from its immediate surroundings.

From moving into the compound to organizing community rituals, the former residents of Miaotou Village appropriated the space on which they were newly settled. The shaping of a public space as well as the organization of ancestor's festivals (even if the latter was transitional) gave them a way to truly settle into their new housing. At the same time, the process was already blurring the meaning of "home" and "family" (expressed in Chinese by the same character jia 家) and of the practices the term refers to. ${ }^{34}$ This blurring would call for innovations to the rituals.

\subsection{Worshipping at Home}

After Miaotou Village moved into the new compounds, the extended families were split into nuclear families. Besides this, as we have already noted, the demolition regulations stipulated that the apartment number of each household was to be determined by lottery. Because of this restructuring, the Miaotou people have become "urban people" in a fashion that goes deeper than the one implied by the change in household registration. At around the time they were moving into their new lodgings, the residents of Miaotou Village were entering a stage when the aging of their small community was

31 At that time, Miaotou Village was still supervised by a "brigade" (dadui 大队) and not by neighborhood committees (juweihui 居委会) as is normally the case in urban settings. The brigade chief was a local, which helped to secure a grant for holding the ritual. (A shift in administrative structure did not occur before March 2019, when the administrative local structure of all the communities of Pengpu Town was normalized, following the standard juweihui model).

32 Mount Huaguo is a popular destination, advertised as the birthplace of Sun Wukong, the celebrated monkey of the novel Journey to the West.

33 For a study on the background and diversity of such rituals: Tam (2018).

34 See below our discussion of the distinction sketched here. 
already a very serious issue. Also, as we have seen, due to the liberalization of the housing market, some residents are being replaced by new ones, who have no connection to the original community, and the number of these new residents is continuously increasing. Today, the only features still evoking the original Miaotou Village, are the presence of the chairs arranged in the community center garden and the "chess rooms", populated almost uniquely by the former villagers.

Though life is increasingly centered upon the nuclear family, extended family linkages are still nurtured through the celebration of rituals, and notably the ones marking the New Year festival. Another ritual of the utmost importance in this community is the celebration for the ancestors at Winter Solstice. The celebration takes place in the nuclear family's apartment, and one invites ancestors to eat an early dinner: the family "calls" (han 喊) the ancestors so they may come back to eat, one pours wine, lights incense, burns tin-foil ingots, after which one kowtows and then takes the dishes to the stove before they are eaten. The meal is prepared according to the customs that also prevail for Chinese New Year. Fish is a requisite, as are rice and snacks. At New Year's Eve, one usually gathers at the home of the older family member(s), where the extended family together eats the usual festive dinner.

The young people of the compound have a schedule shaped by school or professional obligations. Most of the time, they will not be found "at home", so the community atmosphere is mainly defined by the elderly and middle-aged people gathered in the "chess rooms" who do not have to work for the family livelihood or whose work unit (usually a factory) has been closed. The aforementioned people are also the main force participating in ritual events. Seasonal ceremonies are performed at home by an elderly woman although the male owner is considered as the main executant: he has to be the first to raise incense sticks or to bow, whereas preparing the ceremonial meal, purchasing supplies, notifying family members and other cumbersome duties are considered to be the housewife's responsibility. Young people generally participate only in the dinner that closes the ceremony. The elderly know that this state of things cannot be changed: one cannot hope to see the "whole family" present at the time the ritual is performed, as was the case in the past. If the hostess is too old, she will ask her daughter (or her daughter-in-law if the latter is a native) to perform the task on her behalf. However, if the daughter or daughter-in-law is already fully "urbanized", she might not be willing to play an active role in such ceremonies In the compound, though the Winter Solstice ritual is supposed to take place just before or after the day marked on the calendar, each household chooses when to perform it according to the obligations of its members, but there is little variation in the time the ritual is performed. The choice of dishes is also pretty uniform. The women usually go together to the market to buy food in advance, and they seize this opportunity for sharing knowledge about the way the ritual is to be performed. Ceremonial details and food costs are somehow part of one and the same package of "local knowledge".

\section{Displacing Boundaries}

\subsection{Enlarging the Ritual Space (1): The Huangluo Temple in Suzhou}

It is in the course of such sharing that, in 2004, the issue was raised of the excessive fees requested by the Jade Buddha Temple (the most resplendent and well-known temple in Shanghai) in order to affix a tablet for the departed of one's family. ${ }^{35}$ Then, a woman named Zhang (章) mentioned the fact that it was always possible to go to the Huangluo Temple (皇罗禅寺) in Suzhou: the fees there are cheaper, and it is close to Shanghai. On this suggestion, one by one, the elderly people of more than twenty families of the compound (mainly originating from the former Xia and Zhang Residences)

35 In Shanghai, the memorial tablet (paiwei 牌位) affixed in a temple nowadays seems to substitute for the ancestor's tablet put into family temples or ancestors halls. These buildings disappeared during the Cultural Revolution, and in Shanghai, contrarily to what happened in other regions, they could not be revived afterwards. Temples also allow for lighting a lamp for the deceased. Additionally, they offer ritual spaces for attracting blessings on the living; one of the most popular ways of proceedings is to write on an "auspicious card" (jixiangka 吉祥卡): the name of the person needing special protection, and to put the card in the hand of the bodhisattva Guanyin (观音). Fees charged by temples generally cover one year of service. 
decided to have their funerary tablets affixed in Suzhou. Since then, the community organizes a trip by chartered bus to the Suzhou temple twice a year for worshipping at the time of Qingming (清明) $)^{36}$ and Winter Solstice.

Huangluo Temple is located on the bank of Yangcheng Lake (阳澄湖). The journey from Shanghai takes $1 \mathrm{~h}$ and $30 \mathrm{~min}$. One of the authors of this study joined the trip for the Winter Solstice of 2017. In the early morning, there were buses all along the way to the temple, groups of the faithful there to participate in various events organized by the temple but also to perform devotions of their own in all corners of the courtyard in front of the main hall.

A short walk along Yangcheng Lake leads to the place, clearly indicated by a number of signposts. In addition to the Huangluo Temple, there are two other Buddhist temples nearby. Once you have passed through a majestic archway you see the new and large temple complex. According to the temple's self-introduction it was founded in the middle of the Tang Dynasty, destroyed during the Great Leap Forward (1958), rebuilt in 1995, and expanded in 1999. As was the case for traditional temple fairs (miaohui 庙会), booths occupy the east, west and main entrances of the temple. On that day, many hawkers claiming to be local farmers were also selling from their baskets winter vegetables such as yellow sprouts and radishes, as well as clams, duck and goose eggs. From the Heavenly Kings Hall (after the first courtyard) to the Hall of the Great Hero and to the Patriarch Hall, there were almost no monks to be seen. The Heavenly Kings Hall is accessible only through the South Gate. On the three other sides, Buddha statues or small tables blocking the door were placed. At each table, were seated observant lay Buddhists (jushi 居士) or ordinary believers filling in "forms" used for preparing a tablet. The people in attendance were older women, omnipresent in the three halls of this Buddhist compound. In the Dizang (地 $)^{37}$ Hall, where the funerary tables are affixed, believers were bringing offerings.

The accent of most of the people present was Shanghainese, and the dialect specific to Suzhou was comparatively rarely heard. The leaflet introducing the temple specifically mentions that it was expanded "due to the help of people from Shanghai, Suzhou and other places." All of this shows the close relationship between this temple and Shanghai.

\subsection{Enlarging the Ritual Space (2): The Furongshan Shuangshaxian Temple in Wuxi}

The trip from Guangzhong Court to Suzhou takes place twice or sometimes three times a year; for comparatively small-scale memorial services ${ }^{38}$ and during the seventh lunar month (Ghost Month, guiyue 鬼月) or sometimes at the time of the Winter Solstice. Devotions are centered around ancestors, as their funerary tablets are deposited in the temple. Another trip takes place at the time of Qingming, not in Suzhou this time, but in Wuxi, at the Furongshan Shuangshaxian (芙蓉山双刹贤) temple (see Figure 2). And this trip coincides with the temple holding a full Water and Land Dharma Service. ${ }^{39}$ Though this Buddhist ritual centers around the liberation of all sentient beings, residents of Guangzhong Court state clearly that they undertake the trip and organize the service for the sake of their own relatives.

Why Wuxi's Furongshan Shuangshaxian Temple? Huangluo Temple offers bargains when it comes to funerary tablets, but it was not offering the full-fledged Water and Land Dharma Service till 2018. As to Haining Temple, the price it was requiring for such service were excessive: the fees used to be 10,000 RMB for the inclusion of a deceased person's name on the list of the ones benefiting from

36 Tomb-Sweeping Day, observed on April 5. In Shanghai, the traditional visits to family graves takes place approximately from two weeks before that day till two weeks after.

37 Dizang is the bodhisattva known for his vow to accomplish the task of emptying all hells before entering into the state of Buddhahood. It is usually in the Hall dedicated to him that memorial tablets are affixed.

38 The Huangluo Temple specializes in a ritual called wangsheng pufo 往生普佛, normally performed for the souls of people who have died very recently, but similar rituals, short in duration, take place for the souls of people who may have passed away a long time ago.

39 The Water and Land Dharma Service (Shuilu Pudu Dazhai Shenghui 水普度大) is a solemn and elaborate Buddhist liturgy for the liberation of all sentient beings. 
the ritual, and in 2019 they even reached 15,000 RMB. "These are for the bosses not for the ordinary people", as our informants put it. In Wuxi, the corresponding fee is only of 1000 RMB. Besides, add the same informants, the monk from the Furongshan Shuangshaxian Temple with whom they are most closely in contact is a Shanghainese.

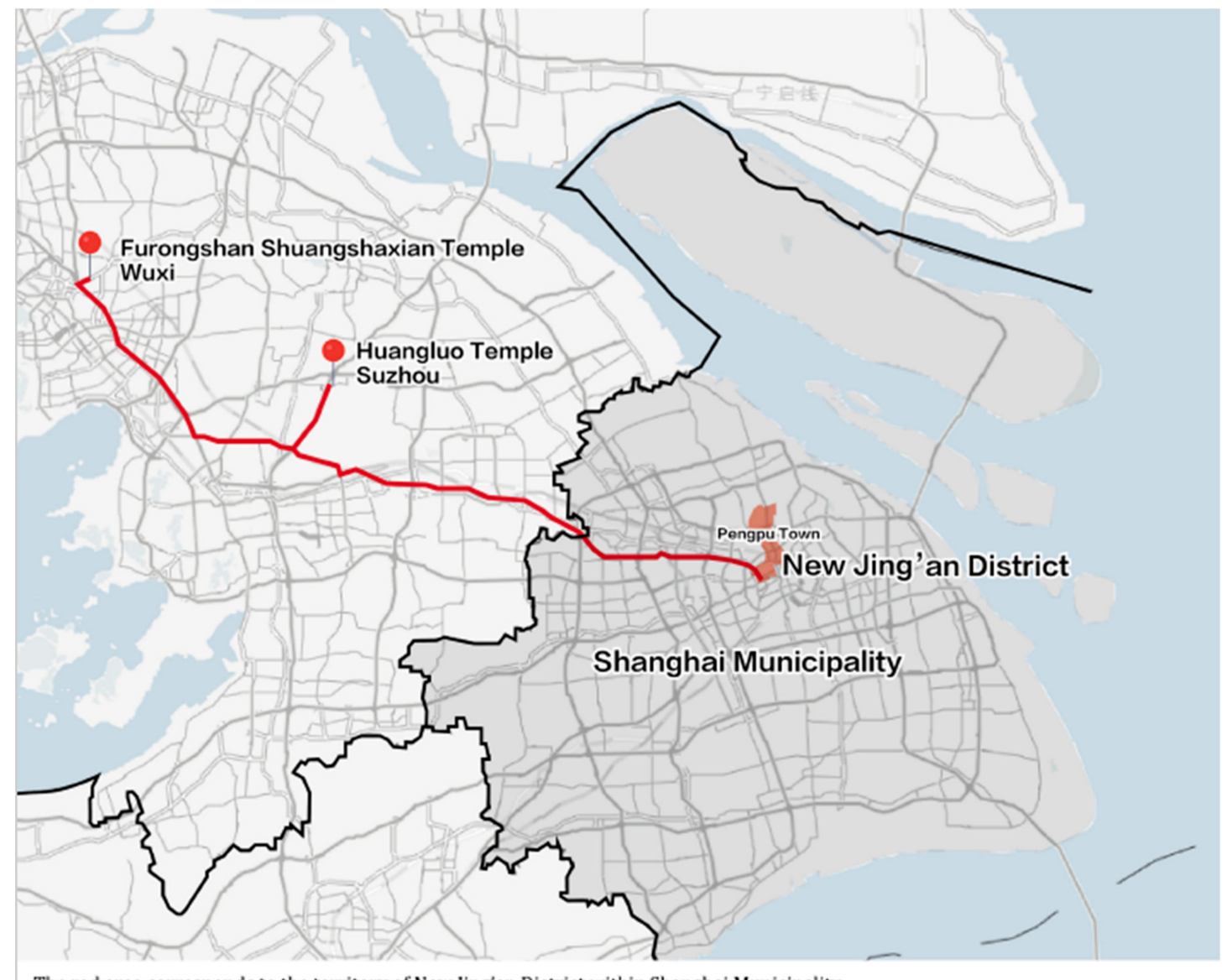

Figure 2. The Compounds in Context.

Further questioning unfolds the thread of a longer story, which starts shortly before the demolition of the village. In the 1990s, a group of ladies from different houses of the Xia Residence started to gather regularly at the home of an old woman believed to possess extra-sensory gifts. The diviner was living alone in a house nearby the Xia Residence. This circle slowly enlarged, and its gatherings came with the frequent burning of incense in front of the Buddhist statues adorning the altar of the diviner, followed by a yearly pilgrimage to a temple, Lingyanshan (灵岩山), located near Suzhou. The death of the diviner left the small community without a clear leader. At that time, the influence of Grandma Jin, whom we discussed earlier, came to assert itself, and she was recognized as the spiritual leader of the group. She was already visiting Haining Temple with the wife of her nephew, a woman of frail health but engaged in various trades and possessing extended connections, who had become an active promoter of this particular temple (in which she was considered a dahufa 大护法, e.g., a person who donates or directs important donations towards the temple). The premature death of this niece did not interrupt the connection: in 2004, after the death of several elders anguished the Guangzhong Court community, it was quite natural for Grandma Jin to call for monks from Haining Temple to come and perform the ritual.

The reasons for eventually electing Huangluo Temple (in Suzhou) and Shuangshaxian Temple (in Wuxi) into what can be now considered the "ritual sphere" of the Guangzhong compound are 
complex. For sure, the pricing of the services linked to funerary affairs was an important element, which triggered a "spiritual migration" towards the place where the afterlife destiny of the departed is cared for. Other factors need to be considered: As we have seen, the adjacent Baohua Temple has been the scene of some community rituals and remains a site of private worship, but it being so close to the compound does not necessarily work to its advantage. (Besides, Buddhist volunteers from the compound do not hold its monks' ritual “efficacy" (ling 灵) in high esteem. ${ }^{40}$ ) On the other hand, locations in Wuxi and Suzhou provide worshippers some distance from the local authorities while remaining easily accessible, and they offer reasonable pricing each for a specific ritual service. The choice of temples both located in adjacent parts of Jiangsu Province may also testify to the persistence of a specifically northern Shanghai identity: not only is the ancestry of North Shanghai's native population closely related to this part of Jiangsu, but also the choice of temples located in Jiangsu over the metropolis' religious landmarks can be interpreted as a reaction against the culture specific to downtown Shanghai: in the main temples of the city, religious services are indeed often overpriced; besides, the spiritual needs and ritual requirements of the upper middle class inhabitants of central Shanghai, which tend to emphasize "technologies of salvation" (Tarocco 2015) centered on the individual, may clash with the ones of a population that, notwithstanding the changes having occurred, remains focused on family-centered rituals. ${ }^{41}$

\section{Transformations in the Spacetime}

\subsection{The Fluidity of "Home"}

We have already underlined changes occurring in the community: old people having originally moved into the new compound are gradually fading away, the young and middle-aged follow the metropolis' timetable, and the proportion of "non-natives" inhabiting the compound gradually increasing. This explains why rituals take place less and less within the community proper, and many elderly people choose to go to the temple as a group, so as to perform rituals that should have taken place at home. The above-mentioned Winter Solstice ritual in the Huangluo Temple is a case in point. The first generation of residents, all of them having worked in agriculture, attaches crucial importance to traditional festivals and the calendrical succession of solar terms. Even if they do not live in a farming community any more, these residents will organize group activities according to custom-related rituals more spontaneously than urbanites do. For, example, they purchase together what is needed for preparing the Qingming Festival, and then associate for stacking ingots to be disposed over the graves. They proceed in the same way at the time of Dragon Boat Festival when making dumplings. On the 15th day of the seventh lunar month none of them forget to burn ingots under their apartments in the compound's garden. ${ }^{42}$ They make slippers in the summer, woolen caps in the autumn, porridge on the day of Laba Festival (腊八节, the eighth day of the twelfth lunar month ${ }^{43}$ ), and, as we have seen, purchases needed to prepare the Winter Solstice are also conducted together. Almost all the restaurants in the neighborhood are populated by locals: the former custom was that, once "rituals" had been completed (this included children's exams, moving home, rituals for the departed at regular intervals,

40 Once, women from the compound participated as volunteers to a ceremony held in Baohua Temple to the benefit of children of schools located nearby. They observed that the monks had invited ritual masters from outside, and drew their own conclusions from this fact.

41 Differences among temples are relative. However, although they continue to perform "traditional" services, the fact that the main Buddhist temples of Shanghai cater to the needs of a more affluent population and are part of the representation that "Global Shanghai" offers to the country and to the world creates a gap between their spiritual offering and the needs (as well as the means) of the people living at the periphery.

42 With accrued controls now taking place, holding such ritual activities becomes more problematic. Our informants congratulate themselves that, most inhabitants of the two compounds being "locals", no complaint is generally registered when ingots are burned on the premises, while neighboring communities see such activities more and more severely restrained.

43 This is a day when offerings to the ancestors are made; it also coincides with the one celebrating the Awakening of the Buddha. 
weddings, the consumption of tofu rice after funerals), a meal would be cooked and offered in the village's open space. As such open space is not available anymore, the meals take place in restaurants.

This testifies to the fact that the biggest change brought by modernization to the former residents of Miaotou Village is that "home space" has been drastically reduced, obliging people to "go out to do things" (chuqu banshi 出去办事), e.g., to perform important ritual activities outside the home space. At the same time, the compound cannot meet the functions fulfilled by the former village space; the sense of ownership of the land and the identity attached to it has necessarily faded. Behind the claim to be "local", hides the question of how to reshape the home space: does home correspond to the apartment proper? To the compound? To the cemetery, where the ashes of the departed rest? To the temple's Dizang Hall where funerary tablets are affixed? Such questions do not weigh only upon the present life but on the afterlife as well, and upon what needs to be done so as to prepare for it: prices for a cemetery slot are increasing by the day; therefore, many locals have to relocate family tombs to cemeteries located at the junction of Baoshan District and Jiangsu Province. And the money involved makes it impossible to affix funerary tablets in local temples, which concurs, as we have seen, with the "spiritual migration" towards the Suzhou suburbs. The reduction of the home space has caused many elderly people to spread the sense of sacredness linked to one's home towards new places: the temple's Hall where tables are affixed; temples where Water and Land Dharma Services take place, and shrines visited at Chinese New Year or for the Winter Solstice (when, in the past, this latter occurrence was celebrated solely at home).

\subsection{Fluidity, Resilience and Virtualization}

Paradoxically, the interweaving of ritual practices and sacred places that we just documented is not due merely to the shift in the identity of a given geo-community, but also, and even more so, to both the fluidity and the resilience of what "home" and "family" are about. Actually, jia has multiple meanings-besides the ones we just mentioned, it may speak of a "school of thought" and, by extension, of someone "expert" in one domain or another (e.g., of someone who belongs to a professional grouping). It refers to a lived reality that somehow escapes definition. This explains the fluidity of the practices through which related experience and beliefs are expressed. At the same time, these experience and beliefs are less easily embodied into spatial markers than was the case before. They tend more and more to refer to "virtualized" realities. Let us break down and illustrate the process we just summarized.

A direct and obvious consequence of the urbanization process is that farmers integrated into the urban fabric no longer form a well-defined geo-community, even when relocated at a very close distance from their original residences. Marketization, changed land use and new forms of housing make the transformation radical and irreversible, as testified by the experience that the Miaotou villagers have endured during the past twenty years (and especially during the last ten years, as the chain represented by elderly people's memories and ways of doing things has seen its links weakened during that time). On the one hand, the frontiers of one's "home" have become expanded and diffuse; on the other, the reality the term represents may have become even more sacred than before, as the realities it embodies-memories, solidarities, customs, ways of relating to the otherworld-are under attack by the very texture of urban life. "Home" is diffuse; its expressions have become fluid and transient. The tentative representation that its contemporary features may evoke would be of a string made of knots that need to be tied into a whole.

Moreover, jia has always been a multilayered and evolving reality (Freedman 1958; Cohen 1976), especially when lineages were built around the holding of corporate estates, a case much more frequent in southeastern China (Wolf and Huang 1980; Faure 1986). Furthermore, "homes", "residences" and "villages" have never been isolated realities: they were inserted into a network of affiliations. Visits to communal temples and market fairs were symbolizing and nurturing the layers construing these networks. Therefore, the shift that our case-study documents is not about the fact that temples located outside the communal territory are now being visited, or that "family", "home" and "household" are 
realities that are lived and expressed at various levels. It rather bears on the radicalness of the relocation process, and on the "ritual answers" crafted by "actors" dispossessed of agency. Our narrative both resounds and contrasts with the one penned by Selina Chan about the way the selling of corporate land holdings affected a lineage established in Hong Kong's New Territories (Chan 2001). In the case discussed by Chan, the sale of corporate land was progressive, negotiated and strategized; it did not go with the destruction of the villagers' homes, but rather with their renovation; it was preceded and accompanied by migration to foreign countries, which gave more solemnity to subsequent lineages' gatherings and rituals. At the same time, it might be that, in our case-study as in Hong Kong, the separation having occurred between land ownership and lineage has fostered a new approach to the latter as "imagined community" (Chan 2001, p. 281).

In the context of North Shanghai, what can be called the" virtualization" of jia can be illustrated by the following example:

Grandma Shen (沈) had married into the Xia residence. Her husband passed away in 2004—one of the elders whose passing triggered the organization of an ancestors' ritual that same year. During the last months of his existence, she was taking care of her husband at home, and, following the suggestion of a neighbor, asked a local woman diviner (xianren 仙人) ${ }^{44}$ whether there was a cure to the illness. The diviner suggested to communicate the matter to the ancestors (laozuzong 老祖宗) and to ask for their protection. Grandma Shen thus carried out a private ceremony. At a time determined by divination, which happened to be midnight, accompanied by her children she walked along the neighboring park to the corner where the old residence used to stand. At the estimated location of the house the family was inhabiting within the residence, they burnt spirit money and recited incantations to the spirits. It is striking that this private ritual took place around four years after having duly informed the ancestors of the move into the new compound.

Grandma Shen is part of the core group that pays regular visits to the Suzhou and Wuxi temples. Until today, when she is asked "where is home" (wen jia 问家) she spontaneously answers that home is the Xia residence. Guangzhong Court, she adds, is the place where Miaotou Village has requested the residents to resettle. So, jia is now primarily identified to a plot of land that, in the new urban landscape, has become undistinguishable. This parcel of territory remains loaded with the spiritual power linked to Grandma Shen's late husband's lineage. At the same time, the disappearance of the materiality of $j i a$ has provoked a dispersal of some of its affective and ritual dimensions towards the compound's apartments ${ }^{45}$ as well as towards the temples where community outings and family worship can mix into one.

\section{Conclusions}

Several conclusions can be drawn from our study of the transformation of the Miaotou Village into gated communities:

The ritual expressions that were typical of a Chinese village's social and religious life have been severely affected by the urbanization process, and many are in the process of disappearing altogether. Yet, seen from another perspective, a good number of them have been merely evolving, with some new customs easily substituting for the former ones-such is the case of the post-ritual meal at the restaurant taking the place of the one cooked in the village's open space. The celebration of rituals by "family representatives' rather than by the gathering of the whole family is another example of the adaptations taking place. ${ }^{46}$

44 In local parlance, xianren refers to a woman who communicates with spirits and Daoist deities, and is expert at divination. In the present Chinese context, such persons are mentioned with much reticence. Even with acquaintances, one generally avoids to mention the fact that one may at times resort to them.

45 The plural is justified by the fact that rituals and festive occasions take place in Grandma Shen's apartment as well as in the ones of her children.

46 The fact is not a novelty, as there are examples in some regions of ritual meals after lineage ceremonies where only male household heads participate. What is important here is that it constitutes an innovation for our villagers. 
The plasticity of ritual practices that makes them at least partly perdure even in extremely adverse circumstances can be explained by the steadfastness of the underlying representations through which they are sustained. Of particular importance is the status given to jia as a community that links together the departed and the living, a community that needs to be ritualistically preserved and nurtured whatever the adaptations and compromises that changing times and material circumstances call for.

As already underlined by Fei Xiaotong (Fei 1992), kinship, in traditional China, "was about networks of relationships organized around status differences and status orderings" (Harrell 2013, p. 73) — which, by itself, was making it a dynamic and evolving reality Still, jia used to be incarnated, rooted into a parcel of land (whatever its mode of ownership and insertion into a given settlement). When this material anchorage altogether disappears, the fluidity and multilayered character of the "home" reference extends to the extreme, making the representations of jia becoming virtual or "imagined." 47

At the same time, the sacredness of "home" is progressively transferred to other settings, first and foremost the (public) ones in which ancestor rituals take place. ${ }^{48}$ By the very fact of loading public places of worship with some of the "home" characteristics, the new model of urban religiosity also gives accrued importance to official religious expressions over popular ones-in our case, explicit adherence to Buddhism becomes a defining feature. In other cases, this may benefit Christianity or even official Daoism.

While the disappearance of elderly people originating from traditional communities further accelerates the eroding effects triggered by urbanization, it should be noted that the process of ritual transmission is socially maintained through women. Here, one point cannot be elucidated yet: will the present and coming generations of fully "urbanized" women mark a decisive stop in the transmission chain, as these women would relinquish a ritual inheritance that loads them with a time-consuming burden, or will a sustained sense of what a "family" is meant to be induce them to come up with renewed yet recognizable ritual markers?

The former inhabitants of Miaotou Village have experienced the demolition and relocation process that has taken place in Shanghai between, roughly, 1990 and 2010; their trajectory illustrates the way the boundary between rural and urban identities has been moving; they are also emblematic of a social and religious ethos that contributes to define North Shanghai. Located as they are on geographical, temporal, social and ritual frontier lines, they have become privileged witnesses of a transformation process that, in China has happened on an unprecedented scale. They are testifying to the sustainability of a core set of beliefs as well as to the plasticity, if not the frailty, of the ritual practices that used to embody them. Twenty years from now, "Chinese religion" as lived in metropolises will possibly have become almost unrecognizable from its rural expressions. At the same time, its reinvention could be fostered by the set of representations it continues to convey and by the urbanites' ritual inventiveness.

Author Contributions: Investigation, J.C.; Methodology, B.V.; Supervision, B.V.; Writing—original draft, J.C.; Writing-review \& editing, B.V.

Conflicts of Interest: The authors declare no conflict of interest

\section{References}

Anonymous. 2007. The little village that shows the splendor of city [life]: Recording the urbanization of Miaotou Village, Pengpu Town, Zhabei District. 演绎都市辉煌的小村庄一闸北区彭浦镇庙头村城市化纪实. Rural Economy of Shanghai 上海农村经济 2007: 24-25.

47 Thanks to two anonymous reviewers as well as to Stevan Harrell for their most helpful remarks on the multilayered reality embodied into the term "jia".

48 This raises a set of questions that would trigger a complementary research: how are "cultural" or "ritual" intimacies that were first developed at home transferred into a public setting, for instance a temple? And how is a public setting "made" to feel like home through the transfer of these intimacies? (See the way Herzfeld 2015 frames similar issues.) 
Cao, Nanlai. 2010. Constructing China's Jerusalem: Christians, Power, and Place in Contemporary Wenzhou. Stanford: Stanford University Press.

Chan, Selina Ching. 1998. Politicizing tradition: The identity of indigenous inhabitants in Hong Kong. Ethnology 37: 39-54. [CrossRef]

Chan, Selina Ching. 2001. Selling the Ancestors' Land: A Hong Kong Lineage Adapts. Modern China 27: $262-84$. [CrossRef]

Chau, Adam Yuet. 2019. Religion in China. Cambridge: Polity.

Cohen, Myron. 1976. House United, House Divided: The Chinese Family in Taiwan. New York: Columbia University Press.

DeGlopper, Donalrd R. 1995. Lukang: Commerce and Community in a Chinese City. Albany: State University of New York Press.

Duan, Qi. 2011. How the Loss of Balance of Religious Ecology Influences the Development of Christianity. An Example from Xugan County in Jiangxi Province. 宗教生态失衡对基督教发展的影响一以江西 余干县的宗教调查为例. China Academic Network on Religions 中国宗教学术网. Available online: http: //iwr.cass.cn/jdjyjs/lw/201101/t20110107_3111612.shtml (accessed on 20 July 2019).

Farrell, Kyle, and Hans Westlund. 2018. China's rapid urban ascent: An examination into the components of urban growth. Asian Geographer 35: 85-106. [CrossRef]

Faure, David. 1986. The Structure of Chinese Rural Society: Lineage and Village in the Eastern New Territories. New York: Oxford University Press.

Fei, Xiaotong. 1992. From the Soil: The Foundations of Chinese Society; A Translation of Fei Xiaotong's "Xiangtu Zhongguo". Translated by Gary G. Hamilton, and Wang Zheng. Berkeley: University of California Press. First published 1947.

Freedman, Maurice. 1958. Lineage Organization in Southeastern China. London: Athlone.

Ge, Zhuang. 2013. A Survey of Modern Buddhist Culture in Shanghai. Chinese Studies in History 46: 79-94.

Geertz, Clifford. 1973. The Interpretation of Cultures. New York: Basic Books.

Goossaert, Vincent, and David A. Palmer. 2011. The Religious Question in Modern China. Chicago: The University of Chicago Press.

Granet, Marcel. 1977. The Religion of the Chinese People, Maurice Freedman Trans. New York: Harper \& Collins. First published 1922.

Hamashima, Atsutoshi. 2011. Communal Religion in Jiangnan Delta Rural Villages in Late Imperial China. International Journal of Asian Studies 8: 127-62.

Harrell, Stevan. 2013. Orthodoxy, resistance, and the family in Chinese art. In The Family Model in Chinese Art and Culture. Edited by Jerome Silbergeld and Dora C.Y. Ching. Princeton: Princeton University Press, pp. 71-88.

Herzfeld, Michael. 2015. Practical Piety: Intimate Devotions in Urban Space. Journal of Religious and Political Practice 1: 22-38. [CrossRef]

Hingley, Liz, Benoît Vermander, and Liang Zhang. 2016. (Re)locating sacredness in Shanghai. Social Compass 63: 38-56. [CrossRef]

Huang, Jianbo. 2014. Being Christians in Urbanizing China: The Epistemological Tensions of the Rural Churches in the City. Current Anthropology 55, (Special issue 10): S238-47.

Huang, Weishan. 2012. The Bodhisattva Comes Out of the Closet: City, Surveillance, and Doing Religion. Politics and Religion Journal 6: 199-216.

Kang, Jie. 2016. House Church Christianity in China: From Rural Preachers to City Pastors. New York: Palgrave Macmillan.

Lagerwey, John. 2010. China. A Religious State. Hong Kong: Hong Kong University Press.

Lagerwey, John. 2019. Paradigm Shifts in Early and Modern Chinese Religion. Leiden: Brill.

Li, Tiangang. 2017. Jinze. A Probe into the Origin of Jiangnan Popular Sacrificial Rituals. 金泽一江南民间祭祀探源. Beijing: SDX Joint Publishing Company.

Paper, Jordan. 2019. Chinese Religion and Familism. The Basis of Chinese Culture, Society, and Government. London and New York: Bloomsbury Academic.

Qian, Juxi. 2014. Deciphering the Prevalence of Neighborhood Enclosure Amidst Post-1949 Chinese Cities: A Critical Synthesis. Journal of Planning Literature 29: 3-19. [CrossRef]

Rudolph, Michael. 2008. Ritual Performances as Authenticating Practices, Cultural Representations of Taiwan's Aborigenes in Times of Political Changes. Berlin: LIT Verlag. 
Sargeson, Sally. 2013. Violence as development: Land expropriation and China's urbanization. Journal of Peasant Studies 40: 1063-85. [CrossRef]

Shryock, J. Knight. 1931. The Temples of Anking and Their Cults: A Study of Modern Chinese Religion. Paris: P. Geuthner. Skinner, George William, ed. 1977. The City in Late Imperial China. Stanford: Stanford University Press.

Tam, Wai Lun. 2018. Unity in diversity: The deliverance of soul ritual in south China. Studies in Chinese Religions 4: 112-37. [CrossRef]

Tambiah, Stanley J. 1979. A Performative Approach to Rituals. Proceedings of the British Academy 65: 113-69.

Tarocco, Francesca. 2015. The City and the Pagoda: Buddhist Spatial Tactics in Shanghai. In Handbook of Religion and the Asian City: Aspiration and Urbanization in the Twenty-First Century. Edited by Peter van der Veer. Berkeley: University of California Press, pp. 37-51.

United Nations. 2014. World Urbanization Prospects. ST/ESA/SER.A/366. New York: Department of Economic and Social Affairs.

van der Veer, Peter, ed. 2015. Handbook of Religion and the Asian City. Aspiration and Urbanization in the Twenty-First Century. Berkeley: University of California Press.

Vermander, Benoît. 2014. Corporate Social Responsibility in China. A Vision, an Assessment and a Blueprint. Singapore: World Scientific.

Vermander, Benoît, Liz Hingley, and Liang Zhang. 2018. Shanghai Sacred. The Religious Landscape of a Global City . Seattle: University of Washington Press.

Wang, Hongbing, and Dorina Pojani. 2019. The challenge of opening up gated communities in Shanghai. Journal of Urban Design. [CrossRef]

Wolf, Arthur, and Chieh-shan Huang. 1980. Marriage and Adoption in China, 1845-1945. Stanford: Stanford University Press.

World Bank and Development Research Center of the State Council, the People's Republic of China. 2014. Urban China. Towards Efficient, Inclusive, and Sustainable Urbanization. Washington: World Bank. [CrossRef]

Worldometers. 2019. China Population. Available online: http://www.worldometers.info/world-population/chinapopulation/ (accessed on 20 July 2019).

Yang, Fenggang. 2005. Lost in the Market, Saved at McDonald's: Conversion to Christianity in Urban China. Journal for the Scientific Study of Religion 44: 423-41. [CrossRef]

Yao, Xinzhong. 2007. Religious Beliefs and Practices in Urban China 1995-2005. Journal of Contemporary Religion 22: 169-85. [CrossRef]

Yip, Ngai Ming. 2012. Walled without gates: Gated communities in Shanghai. Urban Geography 33: 221-36. [CrossRef]

(C) 2019 by the authors. Licensee MDPI, Basel, Switzerland. This article is an open access article distributed under the terms and conditions of the Creative Commons Attribution (CC BY) license (http://creativecommons.org/licenses/by/4.0/). 